\title{
Bribes for Sales: Evidence from the Second Set of Books
}

\author{
Shawn Cole (HBS) and Anh Tran (Indiana University)*
}

March, 2011

\begin{abstract}
We study a proprietary dataset detailing the terms of over 1,000 sales transactions to 218 firms by a mechanics importer in an Asian country. Kickbacks are commons: 85 firms demand cash kickbacks in order to make a purchase. We find government firms to be the most corrupt, requiring kickbacks $47 \%$ of the time. However, private domestic firms are not free of corruption, with $32 \%$ requiring kickbacks. Perhaps most surprisingly, foreign firms, which offer higher salaries and have more educated employees, are more corrupt than domestic private firms: $40 \%$ of them take kickback. Japanese firms stand out as particularly corrupt. From the selling firm's perspective, transactions with higher kickbacks also have higher prices and higher markups. These findings suggest specific implications for corporate governance in emerging markets, where corruption is often widespread.
\end{abstract}

* Preliminary and incomplete. Please do not post, cite, or circulate. scole@hbs.edu and trananh@indiana.edu. 


\section{Introduction}

Corruption is common in emerging markets, and may stifle economic growth through a range of channels: inefficiently low provision of public goods and services; poor allocation of contracts, and transfers from the public treasury to bureaucrats. While much attention has focused on the misbehavior of local government officials, less scholarly attention has been paid to the role of firms in extra-legal payments. Many multinationals have been known to pay kickbacks in order to sell their products ${ }^{1}$. This problem was so pervasive that OECD countries had to enter an AntiBribery Convention to coordinate their collective action to control bribery in overseas markets. However, bribery is believed to continue in different forms, such as paying large commissions to local traders, so that they can bribe on the behalf of multinationals (Singh 2000, Moran 2006). This illicit practice still remains largely a black box to researchers.

All large organizations (such as a government agency or a private firm), delegate decisionmaking rights to employees. Typically, information frictions limit the organization's ability to provide incentives that induce profit-maximizing (or cost-minimizing) behavior (Jensen and Meckling 1976). Particularly when the supervisor is not the principal, she might not spend sufficient efforts to obtain the information about purchased good's quality and price, thus creating room for misbehavior by employees. The procurement staff then can collude with selling firm to exploit this information rent, contracting to pay a higher than necessary price, with a side-payment made from the selling firm to the buying agent (Laffont and Tirole 1991; Arozamena and Weinschelbaum 2009). Such corrupt behavior can be more serious in government than in private firms: private firms focus

\footnotetext{
${ }^{1}$ For example: Siemens (Hack, 2008) and British Aerospace (Wolf, 2008). 450 U.S. corporations admit paying bribes in overseas market in a SEC survey (Rossbacher and Young 1997).
} 
on maximizing profit and can incentivize their employees to achieve this objective; government firms do not always maximize profit and therefore may not provide employees with sufficient incentive to be honest (Banerjee, Hanna and Mullainathan 2009). In other words, ownership structure can be an important determinant of corruption. Also, the split of the information rent between the selling firm and procurement staff depends on the negotiation power, which in turn may also vary with firms' ownership.

Despite a significant body of theoretical work, empirical evidence on corruption has relied mostly on subjective data, such as surveys of corruption perceptions, which have some inherent limitations (Rose-Ackerman, 2006). ${ }^{2}$ Unsurprisingly, it is difficult to observe and measure the private benefits of employees and the cost that they incur to their firms. To date, the inability to observe these private benefits has made it nearly impossible to say anything about the extent and magnitude of these costs, much less test theoretical predictions.

This paper analyzes the amount of bribe required by buyers in more than one thousand sales transactions. The data are precise, as they come from the accounting software of a trading firm operating in Indochina. ${ }^{3}$ The firm has provided the data to one of the authors on the condition that the identity of the firm and the clients not be disclosed. These unique data allow us to provide some of the first ever precise measurements of corruption, linking the presence and size of extra-legal payments to transaction-level details, as well as corporate governance, ownership, compensation and monitoring. ${ }^{4}$ Internal records of organizations engaging in illicit activities like this one, although difficult to obtain, can provide valuable insight into these activities. Levitt and Venkatesh (2000), for example, use the internal records of a drug-selling gang to understand the incentives faced by gang

\footnotetext{
${ }^{2}$ Even if respondents are willing to respond truthfully, they may not recall the exact details of particular transactions.

${ }^{3}$ Indochina consists of Vietnam, Cambodia and Laos. The firm operates in one of these countries.

${ }^{4}$ Kickbacks are illegal even in transactions which are conducted through private parties.
} 
members. In a similar spirit, our paper provides an inside perspective on the kickback business, which would not be accessible otherwise. Like Levitt and Venkatesh's study, we focus on exposing the operation of the kickback business of one organization, showing relationships between ownership, kickback and profit, and not making econometric arguments about causalities. This paper is one of the first outputs of a larger research program to collect and study actual bribery data from corporations. ${ }^{5}$

Using this confidential dataset, we were able to show for the first time the relationship between firm ownership and employee corruption. Consistent with Shleifer's argument (1998), we find that government ownership is associated with high levels of corruption in sales. Firms with $100 \%$ government ownership have even higher corruption than firms with lower-than-100\% government ownership. Surprisingly, we find that foreign ownership is associated with higher corruption than domestic private ownership. However, firms with 100\% foreign ownership have less corruption than firms with lower-than-100\% foreign ownership. Among foreign firms, OECD firms are significantly less corrupt, with the exception of Japanese firms, which are extremely corrupt. Our analysis suggests that paying higher kickbacks to private firms helps the selling firm to earn higher profit. However, this pattern does not hold for government and foreign firms. This may speak of the role of negotiation power among these firms.

The rest of the paper is structured as follows. Section II discusses descriptive statistics. Section III provides the background of the industrial supplier and describes its sales and bribing practices. Section IV analyzes the relationship between ownership and kickbacks. Section IV studies the relationship between profitability and kickback. The paper ends with a brief discussion of the implication of the results and limitations of the paper.

\footnotetext{
${ }^{5}$ For a detailed description of our research program see Cole and Tran (2011)
} 


\section{Descriptive Statistics}

The dataset, drawn from the importing firms accounting software, covers all sales transactions of this supplier from January 2003 to July 2007. It includes detailed information about: contract values, costs and profits, dates of deposit, invoices, payments and kickbacks, and product name. It also includes client information: name, ownership, industry, address, tax code, size category, and the job title of the person responsible for purchasing. We match these records with administrative data from a government survey of all businesses in the capital city. We were able to match records for 1096 sales transactions with 218 client firms. The descriptive statistics are shown in Table 1.

This trading firm imports industrial equipment and parts from Europe and sells them to firms in the northern region of the country. It has been in this business for more than 10 years and is currently one of the four leading national suppliers in this competitive market. The firm sells to all types of buyers, including private, government and foreign firms. Among the buyers, 61\% are private firms, $23 \%$ are firms (or organizations) with some or full government ownership, 9\% are firms (or organizations) with some or full foreign ownership, and the remaining $6 \%$ have both government and foreign ownership. The average annual revenue, labor force and wage of the buying firms are 389 persons and $\$ 30.4$, respectively. This average labor force and wage include both managerial staff and workers. Government and foreign firms have a much larger labor force than domestic private firms do. Foreign firms pay workers significantly higher than government and private firms do. The average cost of a sales contract is $\$ 1,211$. This is the cost that the selling firm has to pay in order to import the product (we use this cost instead of sales value to avoid having profit on both sides of regression equations). Government contracts are about one and half times 
larger than contracts with foreign or domestic private buyers. This has an implication for negotiation power, which we will discuss in Section III.

The fact that the trading firm sells to a broad base of buyers is useful because it allows us to examine how corruption varies with firm characteristics. Out of these 218 buyers, 85 took kickbacks. As commonly believed, government firms are quite corrupt $-47 \%$ of them took kickbacks. Surprisingly, the level of corruption among private firms is also significant, $32 \%$ of them take kickback. This suggests that agency is also a problem for private firms. For foreign firms, $40 \%$ take kickbacks. The fact that foreign firms are more corrupt than private domestic firms is very intriguing because foreign firms are known for paying higher salaries and having access to better management skills. Our analysis in the next section will explore why it is the case. 


\section{Bribing for Sales in Practice}

The marketing and sales process of this supplier consists of six main steps: identifying potential clients; approaching them; pre-contract negotiations; entering into a contract; receiving payment and (sometimes) giving kickbacks. In the first step, identifying potential clients, the supplier looks for information in business directories, particularly in areas related to its products (heavy industries). It also has stalls at industrial exhibitions. The supplier tries to determine which firms are likely to buy its products.

In the second step, the supplier's sales force approaches the clients identified as leads in the

first step. For a new client, this is a lengthy process. Initially the supplier's salespeople contact the potential client to request a meeting. If the client accepts the offer to meet, the salespeople make a presentation about the products to the CEO or head engineer. After this meeting, the salespeople follow up with several phone calls and possibly further meetings. Many of these efforts do not lead to sales as these firms already buy from different suppliers. After several contacts, some firms may agree to consider purchasing from the supplier.

It might take a few rounds of offers before the client agrees to enter the third step negotiating a procurement contract. They negotiate the price, quality, post-sales services and the kickback if the client shows interest. The request for kickback is initiated by the client. The supplier gives its salespeople a minimum price list and allows them to pay kickbacks up to $5 \%$ of the value of the contract. For any price lower than the listed prices, or for a kickback greater than $5 \%$ of the contract values, the salespeople are required to obtain authorization from the CEO. Competition in the market makes the supplier's offer very similar in quality, price and kickback levels.

If an agreement is reached, the typical process is the following. After signing the contract, the client makes a deposit of roughly $30 \%$ of the contract value, and the supplier places the overseas 
order (a deposit is usually necessary because these products are customized and would be difficult to be sold to other clients.) It takes about 1-2 weeks for the supplier to deliver the product, and the client usually pays the rest of the contract's value at delivery. In some cases, the supplier may allow the client to hold back a small amount (roughly $20 \%$ of the contracted value) until one month after delivery so that the client can make sure that the product meets the specified quality.

The kickback is paid only after all contract payments have been made. This is quite different from the kickback-payment method used by in other firms that deal with larger contract values (see Tran 2011.) When contract values are large, selling firms usually pay kickbacks as a percentage of the actual payment, that is, they do not wait until all payments have been made. Even this supplier mentioned that in a few cases when contract values are high, the buyer insisted part of the kickback be paid before all payments had been made.

Bribing is efficient in the sense that almost all kickbacks are paid in cash. Even though these deals take place in an Asian country with a very strong tradition of exchanging gifts at important holidays (such as on the New Year Eve), buyers express strong preference for cash. Kickbacks simply come in cash stuffed in envelops with the amount written clearly outside. In some instances, the supplier even wires the kickback money through the post office, to recipients in remote areas. This suggests that concern over legal action may be minimal. 


\section{Firms' Ownership and Corruption}

To study the relationship between corruption and ownership, we run the following model:

$$
\text { Kickback }_{i t}=(\text { Government Onwership })_{\mathrm{itt}} \beta_{1}+(\text { Foreign Ownership })_{\mathrm{it}} \beta_{2}+\mathrm{X}_{\mathrm{it}} \beta_{3}+\gamma_{\mathrm{t}}+\varepsilon_{\mathrm{it}}
$$

Each observation is a sales transaction to firm $i$ at time $t$. All models cluster errors by buyer. We measure Kickback $_{i t}$ in two ways: first, as a dummy indicating whether the buyer takes a kickback; second, as the size of the kickback, expressed as a percentage of the cost of the equipment to the importing firm. We measure government ownership either with a dummy for any government ownership, or by breaking this dummy into two separate indicator variables, one for firms with less than 100\% government ownership, and one for firms that are wholly government owned. Our measures of Foreign Ownership are calculated similarly. We do not have the data on the precise number of shares owned by the foreign investors. Control variables $\mathrm{X}_{i t}$ include the buying firm's wage, equipment cost, annual revenue, ratio of computers per worker. We use the latter as a measure of the firms "modernity" or sophistication.

Table 2 reports the results of this model. Columns $1 \mathrm{~A} \& \mathrm{~B}$ through $3 \mathrm{~A} \& \mathrm{~B}$ start with a simplest form of Model (1). Columns $2 \mathrm{~A} \& \mathrm{~B}$ and $4 \mathrm{~A} \&$ and $4 \mathrm{~B}$ distinguish between partial and total government control. The National Enterprise Census provides data on dozens of other characteristics of the buying firms. These characteristics do not enter significantly into the regression, and are not included or reported here. $4 \mathrm{~A} \& \mathrm{~B}$ are our preferred specifications as they control for the key variables which might influence corruption in an organization.

The results show a consistent pattern of the relationship between ownership and corruption, although the level of significance varies across different specifications and corruption measures. 
Quite surprisingly, foreign ownership is reliably associated with higher corruption. In the preferred specification (4A \& 4B), foreign firms are shown to be more likely to take kickbacks than domestic private firms by 23.9 percentage points. Their amount of the required kickback is also 10.2 percentage points higher (as a fraction of equipment cost). Note from Table 1 that foreign firms pay higher wage and use more computers for management. And yet, their employees are still more likely to take kickbacks than employees of domestic private firms. This suggests some problem of managing foreign invested firms. Most employees are local while managers are expats. The ones who take bribes tend to be local employees. Perhaps cultural difference, localized knowledge and distance to headquarters contribute to this agency problem.

However, when foreign investors have a complete control of the firms, corruption seems to be reduced. The probability of taking kickbacks decreases by 3.0 percentage points (not statistically significant), while the amount of kickback goes down by 7.2 percentage points, statistically significant at the 10 percent level. This non-monotonous relationship between foreign ownership and corruption suggests that mixed-ownership firms may be particularly bad at controlling employee behavior.

Government firms provide the most conducive conditions for corruption to flourish. Table 2 shows that government ownership is robustly associated with corruption across all specifications. Columns $4 \mathrm{~A}$ and $4 \mathrm{~B}$ show that government firms take kickbacks more often than private firms by 25.7 percentage points. Their average kickback is also higher by 3.46 percentage points. When the government has 100\% control of a firm, its employees become even more corrupt, taking dramatically higher kickbacks. The size of the kickback increase by 14.4 percentage points when the government owns the entire firm. Government ownership is associated with corruption, and full government ownership is the worst. 
The coefficient on $\log$ cost of equipment is economically and statistically significant. Corruption increases with the equipment value. This positive relationship holds even when corruption is measured as percent of equipment cost, which usually leads to a negative relationship in the presence of measurement errors. Also, Table 2 shows that buying firms' size, wage and the use of computers do not have significant relationship with corruption. The coefficients for wage are uniformly negative, which is consistent with the hypothesis that high wage reduces corruption (Besley and McLaren 2009).

Let us return to the relationship between foreign ownership and corruption, which is rather unexpected. Obviously, foreign ownership is a very general category and investors might come from countries with vastly different norms against corruption. To get a better understanding of foreign ownership, we add a dummy for ownership by OECD countries. When standing alone, this dummy does not appear to have a significant effect on corruption (columns $2 \mathrm{~A}$ and $2 \mathrm{C}$ in Table 3). Among OECD firms, however, Japanese firms are notoriously known for paying bribes. ${ }^{6}$ But it is unclear whether Japanese firms are also susceptible to taking bribes. After including a dummy for Japanese ownership in columns $3 \mathrm{~A}$ and $3 \mathrm{~B}$, the coefficient for OECD becomes strongly negative while the coefficient for Japan is strongly positive. That is, OECD ownership is associated with a decrease of 5.4 percentage points in kickback, but Japanese ownership is associated with an increase of 20.1 percent. Japanese firms seem to allow both giving and taking bribes. Overall, after controlling for Japanese ownership, the coefficient for foreign ownership falls from 10.2 to 6.2 but remains significant. After taking Japan and OECD firms out, foreign firms still take higher kickback than domestic private firms.

\footnotetext{
${ }^{6}$ For example, in 2010 a Japanese consulting firm admitted paying $\$ 820,000$ in kickback to win a contract in this country. This case results in jail sentences for four Japanese businessmen and one local government official.
} 


\section{Paying Kickback and Earning Profit}

In the previous section, we have seen that the level of kickback varies across different ownership types. In this section, we examine whether paying kickbacks is associated with higher profits for the selling firm. A key requirement for corruption to occur is that the principal of the buying firm has less information, particularly about the quality and market price of the purchased goods, than does the buyer. This information is shared by the selling firm and the employees of the buying firms. One question is how this information rent is split between the selling firm and the procurement staff of the buying firms. There are two hypotheses. The first is that staff of an organization with poor incentives (such as a government firm) may have little motivation to negotiate for a good deal for their employer, and therefore would let the seller earn a high profit regardless of kickback size. The second is that staff of an organization that buys a large contract, tend to have more negotiation power and can exact the larger part of the rent. Although these two hypotheses are not mutually exclusive, they lead to opposite predictions in our case. Government firms are known for having poor incentives but at the same time they tend to have large contracts (the average cost of equipment is $47 \%$ higher than that of private firms). The first hypothesis predicts that the profits in the contract with government firms tend to be larger than that of private firms. The second hypothesis predicts the opposite.

Turning to the data, we run the following model:

$$
\begin{aligned}
& \text { Profit }_{i t}=(\text { Kickback })_{i \hbar} \beta_{1}+(\text { Government Onwership })_{i \hbar} \beta_{2}+(\text { Foreign Ownership })_{i} \beta_{3}+(\text { Kickback })_{i t} \\
& *(\text { Government Onwership })_{i \hbar} \beta_{4}+(\text { Kickback })_{i t} *(\text { Foreign Ownership })_{i \hbar} \beta_{5}+\mathrm{X}_{i \hbar} \beta_{3}+\varepsilon_{i t}
\end{aligned}
$$


Similar to Model (1), each observation is a sales transaction to firm $i$ at time $t$. All specifications cluster errors are at the level of the buyer. Profit ${ }_{i t}$ is the profit of the selling firm, excluding the kickback paid. It is measured as percentage of equipment cost. Kickback ${ }_{i t}$ is also measured as percentage of equipment cost. Other variables including (Government Onwership) is, (Foreign Onwership) ${ }_{i t}$ and Control variables $\mathrm{X}_{i t}$ are similar to the ones used in (1). The two interactions $(\text { Kickback })_{i t}^{*}(\text { Government Onwership })_{i t}$ and $(\text { Kickback })_{i t} *(\text { Foreign Ownership })_{i t}$ allow us to see whether kickbacks are associated with different level of returns across different ownership types.

Table 4 reports the results of this model. Column 1 regresses profit on government and foreign ownership. Column 2 regresses profit on kickback, ownerships and the interactions between them. Column 3, adds control variables and year dummies. As a robustness check, columns 4, 5, and 6 replicate column 3 on separate samples of government, foreign, domestic private firms. Columns 2 and 3 show a positive relationship between kickback and profit among domestic private firms. Column 4 runs in the sample of only domestic private firms and provides a result consistent with columns 2 and 3. Its estimate is very close with Column 3 and indicates that one percentage point increase in kickback is associated with roughly 1.2 percentage point increase in sales profit. In both columns 2 and 3, the interaction between government ownership and kickback has a significant negative coefficient, implying that kickbacks to government firms may yield less profit, relative to kickbacks paid to private firms. Column 5, which runs the analysis only on the sample of government firms, shows a negative but insignificant relationship between kickback and profit. This suggests that paying kickbacks to a government firm does not help to increase profit. The interaction of kickback and foreign ownership has a positive but not significant coefficient in column 2 and 3. Column 6 also shows a positive and insignificant relationship between kickback and profit. This might be because we do not have sufficient number of observations, or maybe foreign 
firms are too heterogeneous. The standard errors of kickback are very high, suggesting a large variation among foreign firms. Note that foreign firms come from very different countries.

\section{Conclusion}

In this paper, we analyzed the actual records of kickbacks made by a trading firm to the procurement staff of its client firms. This special dataset allows us for the first time to observe accurately the level of corruption and associated profit from sales to firms of different types. This enables us to compare the seriousness of corruption as a principal-agency problem in various ownership structures. This paper brings in two results about the relationship between corruption and ownership. First, corruption is not only pervasive among government firms but also among foreign firms. Among foreign firms, OECD firms tend to have a significantly lower level of corruption, except for Japanese firms (in our sample), which are very corrupt. When foreign investors control 100\% of buying firms, corruption also goes down. Second, when the selling firm pays higher kickbacks to private firms, it gets higher profit (excluding the kickbacks). This pattern does not hold for government firms, who make large procurement transactions.

In the principal-agency framework, the level of corruption shaped the information asymmetry between the supervisor and procurement staff. The results presented in this paper suggest that such asymmetry might be larger in government and foreign firms than in domestic private firms. And procurement staffs of government firms are able to get a larger share of this information rent, compared to their counterparts in private firms.

Despite these results, we acknowledge the limitations of this dataset. First, we access these confidential records from one firm. It makes it difficult to generalize for the whole market. Although we believe that even if we had access to data from most of the firms in this market, the main results would not change much. This firm is one of the four leading firms in a very competitive industry. 
Competing firms having similar cost and quality generally do not target specific client groups. That is why the client base of this trading firm includes a variety of firm-types and ownership. Second, we do not identify any exogenous sources of variation in ownership, thus cannot argue definitely for the direction of causality. Despite these significant limitations, we think the evidence presented in this paper has helped us to understand better about this important issue.

\section{References}

Arozamena, Leandro, and Federico Weinschelbaum, “The Effect of Corruption on Bidding Behavior in First-Price Auctions”, European Economic Review, 53 (2009), pp. 645-657.

Banerjee, Abhijit, Rema Hanna and Sendhil Mullainathan “Corruption,” MIT mimeo., 2009

Besley, Timothy and John Mclaren, "Taxes and Bribery: the role of wages incentives," The Economic Journal, 1993

Cole, Shawn, and Anh Tran, "Evidence from the Firm: A New Approach to Understanding Corruption" in S. Rose-Ackerman and T. Soreide ed. International Handbook on the Economics of Corruption (Vol II), forthcoming.

Hack, Jens, “Former Siemens Manager Convicted in Bribery Case,” Reuters, Jul 28, 2008.

Laffont, Jean-Jacques, and Jean Tirole, "Auction Design and Favoritism," International Journal of Industrial Organization 9(1991), pp. 9-42.

Levitt, Steven D. and Sudhir Alladi Venkatesh. "An Economic Analysis Of A Drug-Selling Gang's Finances," Quarterly Journal of Economics, 115(3), 2000 
Moran, Theodore H., "How Multinational Investors Evade Developed Country Laws”, Center for Global Development, Working Paper Number 79, February 2006

Rose-Ackerman, Susan, "Introduction and Overview," in International Handbook of the Economics of Corruption, Rose-Ackerman Susan ed. (Northampton, MA: Edward Edgar Publishing, 2006).

Rossbacher, Henry H. and Young Tracy W., “The Foreign Corrupt Practices Act, An American Response to Corruption", In B Rider ed., Corruption: The Enemy Within, Kluwer Law International, 1997.

Shleifer, Andrei, “State Versus Private Ownership”, Journal of Economic Perspectives, 12(4), 1998

Singh, Someshwar, "Privatization and 'Reforms' Spread Corruption", South-North Development Monitor(SUNS), 2000

Tran, Anh, "Can Regulations Reduce Corruption? Evidence from the Internal Records of a Bribe-Paying Firm”'Tran 2011, Indiana University mimeo, 2011

Wolf, Jim, “BAE Says UK Should Hear Corruption Case,” Reuter, Saturday May 24, 2008. 
Table 1. Descriptive Statistics

\begin{tabular}{|c|c|c|c|c|c|}
\hline & Private & Foreign & Government & Foreign \& Government & All \\
\hline \multicolumn{6}{|l|}{ Firm level Data } \\
\hline Number of buying firms & 133 & 20 & 51 & 14 & 218 \\
\hline Percentage of firms by ownership & $61 \%$ & $9 \%$ & $23 \%$ & $6 \%$ & $100 \%$ \\
\hline Number of firms taking kickback & 43 & 8 & 24 & 10 & 85 \\
\hline Percentage of firms taking kickback & $32 \%$ & $40 \%$ & $47 \%$ & $71 \%$ & $39 \%$ \\
\hline Mean number of workers & 126 & 826 & 865 & 522 & 389 \\
\hline Total assets per firm (US\$) & 165,571 & 567,603 & 295,580 & 715,569 & 268,191 \\
\hline Total revenue per firm (US\$) & 115,611 & 754,396 & 350,444 & $1,082,342$ & 291,237 \\
\hline Average number of computers used & 9.71 & 80.55 & 38.27 & 101.57 & 28.79 \\
\hline Average wage per worker (US\$) & 27.98 & 36.81 & 27.81 & 53.91 & 30.42 \\
\hline \multicolumn{6}{|l|}{ Transaction level data } \\
\hline Number of sales transactions & 809 & 40 & 190 & 57 & 1096 \\
\hline Average cost of sales transaction (US\$) & 1,022 & 1,054 & 1,501 & 1,317 & 1,121 \\
\hline Cost of largest transaction (US\$) & 47,763 & 12,193 & 18,060 & 20,076 & 47,763 \\
\hline Cost of smallest transaction (US\$) & 0.52 & 1.22 & 1.87 & 3.91 & 0.52 \\
\hline St. dev of cost of sales transaction & 3,142 & 2,081 & 2,904 & 2,976 & 3,064 \\
\hline Percentage of corrupt transaction & $11.4 \%$ & $32.5 \%$ & $47.4 \%$ & $66.7 \%$ & $21.3 \%$ \\
\hline Kickback as percent of transaction cost & $1.7 \%$ & $4.0 \%$ & $14.0 \%$ & $15.5 \%$ & $4.6 \%$ \\
\hline Selling firm's profit as percent of transaction cost & $76.4 \%$ & $144.6 \%$ & $95.4 \%$ & $118.9 \%$ & $84.3 \%$ \\
\hline
\end{tabular}




\section{Table 2. Ownership and Kickback}

\begin{tabular}{|c|c|c|c|c|c|c|c|c|}
\hline & $\begin{array}{c}1 \mathrm{~A} \\
\text { Any } \\
\text { Kickback } \\
\end{array}$ & $\begin{array}{c}1 \mathrm{~B} \\
\text { Size of } \\
\text { Kickback } \\
\end{array}$ & $\begin{array}{c}2 \mathrm{~A} \\
\text { Any } \\
\text { Kickback } \\
\end{array}$ & $\begin{array}{c}2 \mathrm{~B} \\
\text { Size of } \\
\text { Kickback } \\
\end{array}$ & $\begin{array}{c}\text { 3A } \\
\text { Any } \\
\text { Kickback } \\
\end{array}$ & $\begin{array}{c}\text { 3B } \\
\text { Size of } \\
\text { Kickback } \\
\end{array}$ & $\begin{array}{c}\text { 4A } \\
\text { Any } \\
\text { Kickback } \\
\end{array}$ & $\begin{array}{c}\text { 4B } \\
\text { Size of } \\
\text { Kickback } \\
\end{array}$ \\
\hline Foreign ownership & $\begin{array}{c}0.201^{\star \star} \\
(0.0860)\end{array}$ & $\begin{array}{c}0.0189 \\
(0.0316)\end{array}$ & $\begin{array}{l}0.233^{*} \\
(0.131)\end{array}$ & $\begin{array}{l}0.0901^{* *} \\
(0.0374)\end{array}$ & $\begin{array}{c}0.210^{\star \star} \\
(0.0894)\end{array}$ & $\begin{array}{c}0.0243 \\
(0.0281)\end{array}$ & $\begin{array}{l}0.239 * \\
(0.131)\end{array}$ & $\begin{array}{c}0.102 * \star \\
(0.0393)\end{array}$ \\
\hline Foreign $100 \%$ ownership & & & $\begin{array}{r}-0.0227 \\
(0.182)\end{array}$ & $\begin{array}{l}-0.0666 \\
(0.0412)\end{array}$ & & & $\begin{array}{c}-0.0298 \\
(0.176)\end{array}$ & $\begin{array}{l}-0.0719 * \\
(0.0431)\end{array}$ \\
\hline Government ownership & $\begin{array}{l}0.358^{\star * \star} \\
(0.0651)\end{array}$ & $\begin{array}{l}0.121^{\star \star *} \\
(0.0385)\end{array}$ & $\begin{array}{l}0.319 * * * \\
(0.0950)\end{array}$ & $\begin{array}{c}0.0442^{\star \star \star} \\
(0.0129)\end{array}$ & $\begin{array}{l}0.285^{\star \star \star} \\
(0.0666)\end{array}$ & $\begin{array}{l}0.111^{\star * *} \\
(0.0382)\end{array}$ & $\begin{array}{l}0.257^{* * *} \\
(0.0859)\end{array}$ & $\begin{array}{l}0.0346 * \star \\
(0.0162)\end{array}$ \\
\hline Government $100 \%$ ownership & & & $\begin{array}{l}0.0720 \\
(0.124)\end{array}$ & $\begin{array}{c}0.139 * \star \\
(0.0698)\end{array}$ & & & $\begin{array}{l}0.0506 \\
(0.111)\end{array}$ & $\begin{array}{c}0.144^{\star \star} \\
(0.0721)\end{array}$ \\
\hline Log of cost of transaction & & & & & $\begin{array}{l}0.0457^{\star \star *} \\
(0.00942)\end{array}$ & $\begin{array}{l}0.00692^{\star *} \\
(0.00288)\end{array}$ & $\begin{array}{l}0.0454^{\star * \star} \\
(0.00926)\end{array}$ & $\begin{array}{c}0.00578 * * \star \\
(0.00220)\end{array}$ \\
\hline Log of wage & & & & & $\begin{array}{l}-0.0151 \\
(0.0386)\end{array}$ & $\begin{array}{c}-0.00618 \\
(0.0141)\end{array}$ & $\begin{array}{l}-0.0150 \\
(0.0376)\end{array}$ & $\begin{array}{r}-0.00527 \\
(0.0109)\end{array}$ \\
\hline Log of firm's revenue & & & & & $\begin{array}{l}0.00342 \\
(0.0101)\end{array}$ & $\begin{array}{c}-0.000893 \\
(0.00233)\end{array}$ & $\begin{array}{l}0.00304 \\
(0.0102)\end{array}$ & $\begin{array}{c}-0.00202 \\
(0.00260)\end{array}$ \\
\hline computers per workers & & & & & $\begin{array}{c}0.0382 \\
(0.0765)\end{array}$ & $\begin{array}{c}0.0326 \\
(0.0266)\end{array}$ & $\begin{array}{c}0.0388 \\
(0.0768)\end{array}$ & $\begin{array}{c}0.0343 \\
(0.0269)\end{array}$ \\
\hline Year dummies & & & & & Yes & Yes & Yes & Yes \\
\hline Constant & $\begin{array}{l}0.114^{* * *} \\
(0.0267)\end{array}$ & $\begin{array}{l}0.0174^{\star \star *} \\
(0.00477)\end{array}$ & $\begin{array}{l}0.114^{\star * *} \\
(0.0269)\end{array}$ & $\begin{array}{l}0.0170 * \star * \\
(0.00458)\end{array}$ & $\begin{array}{l}0.0825 \\
(0.139)\end{array}$ & $\begin{array}{c}0.0616 \\
(0.0602)\end{array}$ & $\begin{array}{l}0.0877 \\
(0.136)\end{array}$ & $\begin{array}{c}0.0748 \\
(0.0576)\end{array}$ \\
\hline $\begin{array}{l}\text { Observations } \\
\text { R-squared }\end{array}$ & $\begin{array}{l}1,096 \\
0.180\end{array}$ & $\begin{array}{l}1,090 \\
0.120\end{array}$ & $\begin{array}{l}1,096 \\
0.182\end{array}$ & $\begin{array}{l}1,090 \\
0.157\end{array}$ & $\begin{array}{l}1,068 \\
0.256\end{array}$ & $\begin{array}{l}1,068 \\
0.152\end{array}$ & $\begin{array}{l}1,068 \\
0.257\end{array}$ & $\begin{array}{l}1,068 \\
0.190\end{array}$ \\
\hline
\end{tabular}

Robust standard errors in parenthes

*** $p<0.01,{ }^{* *} p<0.05,{ }^{*} p<0.1$

All specifications cluster errors around buying firms' ID

Kickback is in percent of the cost of the sales transaction 
Table 3. Foreign Ownership and Kickback

\begin{tabular}{|c|c|c|c|c|c|c|}
\hline & $\begin{array}{c}1 \mathrm{~A} \\
\text { If kickback }\end{array}$ & $\begin{array}{c}1 \mathrm{~B} \\
\text { Kickback }\end{array}$ & $\begin{array}{c}2 A \\
\text { If kickback }\end{array}$ & $\begin{array}{c}\text { 2B } \\
\text { Kickback }\end{array}$ & $\begin{array}{c}\text { 3A } \\
\text { If kickback }\end{array}$ & $\begin{array}{c}3 B \\
\text { Kickback }\end{array}$ \\
\hline Foreign ownership & $\begin{array}{c}0.239 * \\
(0.131)\end{array}$ & $\begin{array}{c}0.102^{\star *} \\
(0.0393)\end{array}$ & $\begin{array}{c}0.268 * \\
(0.137)\end{array}$ & $\begin{array}{c}0.0785^{\star \star *} \\
(0.0291)\end{array}$ & $\begin{array}{l}0.225^{\star} \\
(0.132)\end{array}$ & $\begin{array}{l}0.0627^{\star \star} \\
(0.0270)\end{array}$ \\
\hline Foreign $100 \%$ ownership & $\begin{array}{c}-0.0298 \\
(0.176)\end{array}$ & $\begin{array}{l}-0.0719 * \\
(0.0431)\end{array}$ & $\begin{array}{c}-0.0326 \\
(0.174)\end{array}$ & $\begin{array}{l}-0.0696^{\star} \\
(0.0403)\end{array}$ & $\begin{array}{l}0.0965 \\
(0.161)\end{array}$ & $\begin{array}{l}-0.0222 \\
(0.0303)\end{array}$ \\
\hline OECD ownership & & & $\begin{array}{c}-0.0545 \\
(0.162)\end{array}$ & $\begin{array}{c}0.0443 \\
(0.0437)\end{array}$ & $\begin{array}{l}-0.322^{\star *} \\
(0.139)\end{array}$ & $\begin{array}{l}-0.0539 * * \\
(0.0229)\end{array}$ \\
\hline Japanese ownership & & & & & $\begin{array}{c}0.547^{* * *} \\
(0.180)\end{array}$ & $\begin{array}{l}0.201^{\star * \star} \\
(0.0398)\end{array}$ \\
\hline Government ownership & $\begin{array}{l}0.257^{\star \star \star} \\
(0.0859)\end{array}$ & $\begin{array}{l}0.0346 * \star \\
(0.0162)\end{array}$ & $\begin{array}{l}0.256^{\star \star \star} \\
(0.0859)\end{array}$ & $\begin{array}{l}0.0354 * * \\
(0.0163)\end{array}$ & $\begin{array}{l}0.247^{* * *} \\
(0.0866)\end{array}$ & $\begin{array}{l}0.0321^{\star} \\
(0.0164)\end{array}$ \\
\hline Government $100 \%$ ownership & $\begin{array}{l}0.0506 \\
(0.111)\end{array}$ & $\begin{array}{l}0.144^{\star \star} \\
(0.0721)\end{array}$ & $\begin{array}{l}0.0507 \\
(0.111)\end{array}$ & $\begin{array}{c}0.144^{\star *} \\
(0.0722)\end{array}$ & $\begin{array}{l}0.0586 \\
(0.112)\end{array}$ & $\begin{array}{l}0.147^{\star \star} \\
(0.0722)\end{array}$ \\
\hline Log of cost of transaction & $\begin{array}{l}0.0454^{\star \star \star} \\
(0.00926)\end{array}$ & $\begin{array}{c}0.00578^{\star * *} \\
(0.00220)\end{array}$ & $\begin{array}{l}0.0453^{\star \star *} \\
(0.00923)\end{array}$ & $\begin{array}{c}0.00584^{\star * \star} \\
(0.00219)\end{array}$ & $\begin{array}{l}0.0454^{* \star *} \\
(0.00918)\end{array}$ & $\begin{array}{c}0.00587^{\star * *} \\
(0.00216)\end{array}$ \\
\hline Log of wage & $\begin{array}{l}-0.0150 \\
(0.0376)\end{array}$ & $\begin{array}{l}-0.00527 \\
(0.0109)\end{array}$ & $\begin{array}{l}-0.0149 \\
(0.0376)\end{array}$ & $\begin{array}{l}-0.00534 \\
(0.0109)\end{array}$ & $\begin{array}{l}-0.0142 \\
(0.0362)\end{array}$ & $\begin{array}{l}-0.00506 \\
(0.0106)\end{array}$ \\
\hline Log of firm's revenue & $\begin{array}{l}0.00304 \\
(0.0102)\end{array}$ & $\begin{array}{l}-0.00202 \\
(0.00260)\end{array}$ & $\begin{array}{l}0.00319 \\
(0.0101)\end{array}$ & $\begin{array}{l}-0.00215 \\
(0.00263)\end{array}$ & $\begin{array}{l}0.00247 \\
(0.0101)\end{array}$ & $\begin{array}{l}-0.00241 \\
(0.00264)\end{array}$ \\
\hline computers per workers & $\begin{array}{c}0.0388 \\
(0.0768)\end{array}$ & $\begin{array}{c}0.0343 \\
(0.0269)\end{array}$ & $\begin{array}{c}0.0386 \\
(0.0763)\end{array}$ & $\begin{array}{c}0.0345 \\
(0.0273)\end{array}$ & $\begin{array}{c}0.0232 \\
(0.0752)\end{array}$ & $\begin{array}{c}0.0289 \\
(0.0269)\end{array}$ \\
\hline Year dummies & Yes & Yes & Yes & Yes & Yes & Yes \\
\hline Constant & $\begin{array}{l}0.0877 \\
(0.136)\end{array}$ & $\begin{array}{c}0.0748 \\
(0.0576)\end{array}$ & $\begin{array}{l}0.0869 \\
(0.136)\end{array}$ & $\begin{array}{c}0.0754 \\
(0.0576)\end{array}$ & $\begin{array}{l}0.1000 \\
(0.136)\end{array}$ & $\begin{array}{l}0.0802 \\
(0.0570)\end{array}$ \\
\hline $\begin{array}{l}\text { Observations } \\
\qquad \text { R-squared }\end{array}$ & $\begin{array}{l}1,068 \\
0.257 \\
\end{array}$ & $\begin{array}{l}1,068 \\
0.190 \\
\end{array}$ & $\begin{array}{l}1,068 \\
0.257 \\
\end{array}$ & $\begin{array}{l}1,068 \\
0.191 \\
\end{array}$ & $\begin{array}{l}1,068 \\
0.275 \\
\end{array}$ & $\begin{array}{l}1,068 \\
0.209 \\
\end{array}$ \\
\hline
\end{tabular}

Robust standard errors in parentheses

*** $p<0.01,{ }^{* \star} p<0.05,{ }^{*} p<0.1$

All specifications cluster errors around buying firms' ID

Kickback is in percent of the cost of the sales transaction 
Table 4. Kickback and Profit

\begin{tabular}{|c|c|c|c|c|c|c|}
\hline & $(1)$ & $\begin{array}{c}\text { All firms } \\
(2) \\
\end{array}$ & $(3)$ & $\begin{array}{c}\text { Private } \\
(4)\end{array}$ & $\begin{array}{c}\text { Government } \\
\text { (5) }\end{array}$ & $\begin{array}{c}\text { Foreign } \\
(6) \\
\end{array}$ \\
\hline Kickback & & $\begin{array}{c}1.701^{\star * *} \\
(0.564)\end{array}$ & $\begin{array}{l}1.135^{\star} \\
(0.619)\end{array}$ & $\begin{array}{l}1.198^{\star} \\
(0.636)\end{array}$ & $\begin{array}{l}-0.103 \\
(0.178)\end{array}$ & $\begin{array}{c}0.324 \\
(2.504)\end{array}$ \\
\hline Foreign ownership & $\begin{array}{l}0.440 \star \star \\
(0.183)\end{array}$ & $\begin{array}{c}0.389 \\
(0.254)\end{array}$ & $\begin{array}{c}0.351 \\
(0.260)\end{array}$ & & $\begin{array}{c}-0.0911 \\
(0.291)\end{array}$ & \\
\hline Kickback * Foreign ownership & & $\begin{array}{c}0.313 \\
(0.831)\end{array}$ & $\begin{array}{c}0.401 \\
(0.821)\end{array}$ & & $\begin{array}{l}1.641^{* *} \\
(0.695)\end{array}$ & \\
\hline Government ownership & $\begin{array}{c}0.131 \\
(0.122)\end{array}$ & $\begin{array}{c}0.185 \\
(0.133)\end{array}$ & $\begin{array}{c}-0.0464 \\
(0.119)\end{array}$ & & & $\begin{array}{l}-0.421 \\
(0.372)\end{array}$ \\
\hline Kickback * Government ownership & & $\begin{array}{c}-1.862^{\star \star *} \\
(0.612)\end{array}$ & $\begin{array}{l}-1.213^{\star} \\
(0.646)\end{array}$ & & & $\begin{array}{c}0.823 \\
(2.427)\end{array}$ \\
\hline Log of cost of transaction & & & $\begin{array}{c}-0.0575^{\star \star *} \\
(0.0197)\end{array}$ & $\begin{array}{c}-0.0649 * * \star \\
(0.0233)\end{array}$ & $\begin{array}{l}-0.0549 \\
(0.0381)\end{array}$ & $\begin{array}{l}-0.0526 \\
(0.0864)\end{array}$ \\
\hline Log of wage & & & $\begin{array}{l}-0.0220 \\
(0.0649)\end{array}$ & $\begin{array}{c}0.0251 \\
(0.0692)\end{array}$ & $\begin{array}{l}-0.146 \\
(0.157)\end{array}$ & $\begin{array}{l}-0.279 \\
(0.244)\end{array}$ \\
\hline Log of firm's revenue & & & $\begin{array}{l}0.0374^{\star} \\
(0.0217)\end{array}$ & $\begin{array}{c}0.0235 \\
(0.0236)\end{array}$ & $\begin{array}{c}0.0801 \\
(0.0642)\end{array}$ & $\begin{array}{l}0.0472 \\
(0.100)\end{array}$ \\
\hline computers per workers & & & $\begin{array}{c}-0.503^{\star * *} \\
(0.151)\end{array}$ & $\begin{array}{c}-0.586^{\star \star \star} \\
(0.151)\end{array}$ & $\begin{array}{l}0.0196 \\
(0.660)\end{array}$ & $\begin{array}{c}1.325 \\
(0.963)\end{array}$ \\
\hline Year dummies & & & -0.127 & -0.0353 & $-0.376^{\star \star}$ & -0.201 \\
\hline Constant & $\begin{array}{l}0.775^{\star \star \star} \\
(0.0763)\end{array}$ & $\begin{array}{l}0.745^{\star \star \star} \\
(0.0781)\end{array}$ & $\begin{array}{l}1.151^{* \star \star} \\
(0.277)\end{array}$ & $\begin{array}{c}1.162^{\star \star \star} \\
(0.324)\end{array}$ & $\begin{array}{l}1.035^{\star} \\
(0.612)\end{array}$ & $\begin{array}{l}1.909 * \\
(1.102)\end{array}$ \\
\hline $\begin{array}{l}\text { Observations } \\
\text { R-squared }\end{array}$ & $\begin{array}{l}1,068 \\
0.037 \\
\end{array}$ & $\begin{array}{l}1,068 \\
0.053 \\
\end{array}$ & $\begin{array}{l}1,068 \\
0.152 \\
\end{array}$ & $\begin{array}{c}790 \\
0.169 \\
\end{array}$ & $\begin{array}{c}240 \\
0.164 \\
\end{array}$ & $\begin{array}{c}94 \\
0.130 \\
\end{array}$ \\
\hline
\end{tabular}

Robust standard errors in parentheses

*** $p<0.01,{ }^{* *} p<0.05,{ }^{*} p<0.1$

All specifications cluster errors around buying firms' ID

Kickback is in percent of the cost of the sales transaction 